\title{
Response of 10 Aster Species to Saline Water Irrigation
}

\author{
Shasha Wu
}

College of Landscape Architecture, Fujian Agriculture and Forestry University, No. 15 Shangxiadian Road, Cangshan District, Fuzhou, Fujian 350002, China; and Texas A\&M AgriLife Research Center at El Paso, Texas A\&M University System, 1380 A\&M Circle, El Paso, TX 79927

Youping Sun and Genhua Niu ${ }^{1}$
Texas A\&M AgriLife Research Center at El Paso, Texas
System, 1380 A\&M Circle, El Paso, TX 79927
James Altland
USDA-ARS, 1680 Madison Avenue, Wooster, OH 44691

\section{Raul Cabrera} Rutgers Agricultural Research and Extension Center, Rutgers University,
121 Northville Road, Bridgeton, NJ 08302

Additional index words. Asteraceae, physiological response, salt tolerance

\begin{abstract}
Asteraceae is one of the largest plant families with many important garden ornamental species. Salt tolerance of 10 aster perennials was evaluated in a greenhouse experiment, including the following: damianita (Chrysactinia mexicana), gregg's mistflower (Eupatorium greggii), shasta daisy (Leucanthemum $\times$ superbum 'Becky'), blackfoot daisy (Melampodium leucanthum), lavender cotton (Santolina chamaecyparissus), aromatic aster (Symphyotrichum oblongifolium), copper canyon daisy (Tagetes lemmonii), fournerve daisy (Tetraneuris scaposa), skeleton-leaf goldeneye (Viguiera stenoloba), and zexmenia (Wedelia texana). Plants were irrigated with nutrient solution at electrical conductivity (EC) of $1.2 \mathrm{dS} \cdot \mathrm{m}^{-1}$ (control) or saline solutions at EC of 5.0 or $10.0 \mathrm{dS} \cdot \mathrm{m}^{-1}$ (EC 5 or EC 10) for 5 weeks. Upon termination, growth parameters, foliar salt damage, relative chlorophyll content [Soil-Plant Analysis Development (SPAD) readings], and mineral concentration were measured. Gregg's mistflower, skeleton-leaf goldeneye, and lavender cotton were the most salt-tolerant species with less reductions in shoot dry weight (DW) in both EC 5 and EC 10. Considering the relatively severe foliar salt damage (visual quality score of 3.1 and 2.7 at EC 5; 2.4 and 1.6 at EC 10) and mortality rate $(10 \%$ and $40 \%$ ) in EC 10, aromatic aster and zexmenia should be avoided where poor quality water may be used for irrigation. Gregg's mistflower and skeleton-leaf goldeneye had relatively lower leaf sodium (Na) concentrations suggesting that both species can selectively exclude Na. Damianita and the four daisies, i.e., blackfoot daisy, copper canyon daisy, four-nerve daisy, and shasta daisy, were salt sensitive as evidenced by their greater growth reduction, foliar salt damage, and high $\mathrm{Na}$ and chlorine $(\mathrm{Cl})$ accumulation in leaves, and should be avoided in landscapes where poor quality water may be used for irrigation.
\end{abstract}

Water shortages and poor water quality are critical challenges to gardening and landscaping in many regions of the world and will continue to be a serious issue due to

\footnotetext{
Received for publication 19 Nov. 2015. Accepted for publication 6 Jan. 2016.

This research is supported by a Specific Cooperative Agreement from Department of Agriculture (USDA), Agricultural Research Service, the USDA National Institute of Food and Agriculture Hatch project TEX090450, and Texas A\&M AgriLife Research

The content is solely the responsibility of the authors and does not necessarily represent the official views of the funding agencies. Shasha Wu was a visiting scholar at Texas A\&M AgriLife Research Center at El Paso financed by China Scholarship Council, China.

${ }^{1}$ Corresponding author. E-mail: Youping.sun@ag. tamu.edu or gniu@ag.tamu.edu.
}

climate changes (Cai et al., 2014a). Urban landscape irrigation with alternative water sources such as municipal reclaimed water is common in arid and semiarid regions (Grieve, 2011). A potential problem of using reclaimed water is elevated salt levels, which adversely affects plant growth, development, and causes foliar salt injury on sensitive plants (Cai et al., 2014b; Niu et al., 2012a; Veatch-Blohm et al., 2014). Unlike fruits and vegetables where maximizing yield is the ultimate goal, the maintenance of good aesthetic appearance and blemishfree foliar tissue are important for ornamental plants (Niu and Cabrera, 2010). Therefore, it is important to identify salttolerant plants for areas where poor quality water may be used for irrigation to conserve high-quality potable water, while maintaining an aesthetically appealing landscape (Niu and Rodriguez, 2006).
Asteraceae is an exceedingly large family of flowering plants widespread in the wild and landscape. Many aster species have been studied for salt tolerance, and their responses to salinity are highly dependent on the species. Plains zinnia (Zinnia grandiflora) plants all died at an EC of $7.3 \mathrm{dS} \cdot \mathrm{m}^{-1}$, and chocolate daisy (Berlandiera lyrata) had low survival percentages and low foliar ratings at EC of 5.5 and $7.3 \mathrm{dS} \cdot \mathrm{m}^{-1}$ (Niu et al., 2012a). Treasure flower (Gazania rigen), known as coastal gazania and naturalized on coastal dunes and roadsides in Australia, had 52.5\% greater reduction of shoot DW at $\mathrm{EC}$ of $12 \mathrm{dS} \cdot \mathrm{m}^{-1}$ compared with nonsalinized controls (EC of $0.8 \mathrm{dS} \cdot \mathrm{m}^{-1}$ ), but had no other signs of stress or injury (Niu and Rodriguez, 2006). Seven cultivars of Zinnia marylandica all died when irrigated with EC at 6.0 and $8.2 \mathrm{dS} \cdot \mathrm{m}^{-1}$ for 4 weeks (Niu et al., 2012b). Xeriscaping with native plants is promoted to conserve water, concurrent with use of reclaimed water (Meyer et al., 2009).

We investigated the relative salt tolerance of nine aster species and one hybrid, among which damianita (C. mexicana), gregg's mistflower (E. greggii), blackfoot daisy (M. leucanthum), aromatic aster (S. oblongifolium), four-nerve daisy ( $T$. scaposa), skeleton-leaf goldeneye $(V$. stenoloba), and zexmenia $(W$. texana) are native to Texas. Copper canyon daisy ( $T$. lemmonii) is distributed in the mountains of southern Arizona and adjacent northern Mexico. Like many perennials native to southwestern United States, especially in New Mexico or Texas, most of the species aforementioned are considered drought tolerant (Lady Bird Johnson Wildflower Center, 2015); however, their salt tolerance is unknown. Shasta daisy (Leucanthemum Xsuperbum 'Becky') is perhaps the most popular shasta daisy in the United States because of its sturdy habit and garden dependability (Hawke, 2007). Lavender cotton ( $S$. chamaecyparissus) is also a droughttolerant border, foundation, rock garden, and seashore material; however, little is known on its response to salinity. There is little researchbased knowledge about the responses of the aforementioned aster perennials to salinity. The purposes of this study were to determine the relative salt tolerance by quantifying and comparing the responses of shoot growth, number of flowers, DW, visual quality, chlorophyll content, and mineral concentration of these widely used aster perennials to elevated salinity in a greenhouse experiment.

\section{Materials and Methods}

Plant materials and growing conditions. Rooted cuttings of the 10 species of Asteraceae mentioned above were received from Southwest Perennials (Dallas, TX) on 18 Sept. 2014. Uniform plants were transplanted into 3.9-L pots with equal amount of Metro-Mix 360 (Sun Gro Horticulture, Bellevue, WA) on 6 Oct. and placed in the greenhouse in El Paso, TX $\left(31^{\circ} 45^{\prime} 31^{\prime \prime} \mathrm{N} /\right.$ $\left.106^{\circ} 29^{\prime} 11^{\prime \prime} \mathrm{W}\right)$. Two weeks after transplanting, saline water irrigation treatment was 
initiated. Before treatment, all plants were well irrigated with a nutrient solution with an EC of $1.2 \mathrm{dS} \cdot \mathrm{m}^{-1}$, which was made by adding 1 g. $\mathrm{L}^{-1} 15 \mathrm{~N}-2.2 \mathrm{P}-12.5 \mathrm{~K}$ (Peters 15-5-15 Ca$\mathrm{Mg}$ Special; Scotts, Marysville, $\mathrm{OH}$ ) to reverse osmosis water. The average air temperature in the greenhouse was $26.8{ }^{\circ} \mathrm{C} /$ $21.5^{\circ} \mathrm{C}$ (day/night). The average daily light integral was $12.2 \mathrm{~mol} \cdot \mathrm{m}^{-2} \cdot \mathrm{d}^{-1}$, and the average relative humidity was $40.4 \%$ during the experiment period.

Experimental design and treatments. The experiment used a split-plot design with the salinity treatment as the main plot and 10 species as the subplot with 10 replications per treatment per species. Saline solutions at EC of $5.0 \mathrm{dS} \cdot \mathrm{m}^{-1}$ (EC 5) and $10.0 \mathrm{dS} \cdot \mathrm{m}^{-1}$ (EC 10) were made by adding $1.20 \mathrm{~g} \cdot \mathrm{L}^{-1}$ sodium chloride $(\mathrm{NaCl})$ and $1.16 \mathrm{~g} \cdot \mathrm{L}^{-1}$ calcium chloride $\left(\mathrm{CaCl}_{2}\right)$, and $2.80 \mathrm{~g} \cdot \mathrm{L}^{-1}$ and $2.67 \mathrm{~g} \cdot \mathrm{L}^{-1}$ $\mathrm{CaCl}_{2}$, respectively, to the nutrient solution mentioned above. $\mathrm{pH}$ of the solutions was adjusted to 6.6 to 6.8 . Plants in the control were irrigated with nutrient solution. Both nutrient and saline solutions were prepared in 100-L tanks with confirmed EC using an EC meter (Model B173; Horiba, Ltd., Kyoto, Japan) before irrigation. From 20 Oct. to 17 Nov., irrigation treatments were applied once a week, five times in total. Between the treatment solution irrigations, plants were irrigated with nutrient solution whenever substrate surface became dry. Irrigation frequency varied with environmental condition and treatment. For example, water use of plants at high salinity was less and irrigated less often compared with the plants in the control. At each irrigation, plants were irrigated with $1 \mathrm{~L}$ treatment solution per plant, resulting in a leaching fraction of $\approx 21 \%$. From 17 Nov. until 12 Dec. (termination of the experiment), all plants were irrigated with the nutrient solution because the salinity in the root zone already reached or exceeded the salinity of the treatment solutions.

Leachate EC and survival percentage. The leachate EC was determined following the pour-through methods according to Cavins et al. (2008). Three plants per treatment per species were chosen for measurement each time after saline solution treatment (weekly). The substrate EC were determined using saturated paste extract according to Gavlak et al. (1994) at the end of the experiment. Three pots per treatment per species were measured. Before harvest, the number of dead plants was recorded and survival percentage was calculated.

Growth parameters. Plant height (centimeters), from the juncture point of stem and root to the top growing point (usually to the tallest flower), was recorded at the end of the experiment. Crown diameter (centimeters) at perpendicular directions was also measured. At the end of the experiment, the number of shoots was counted for all species, with the exception that the number of crowns instead of number of shoots in shasta daisy and fournerve daisy was counted due to their rosette growth habit. The criteria for number of shoots for the eight species were made according to their morphological characteristics ( $>10 \mathrm{~cm}$ for gregg's mistflower; $>5 \mathrm{~cm}$ for damianita, blackfoot daisy, aromatic aster, and skeleton-leaf goldeneye; $>3 \mathrm{~cm}$ for lavender cotton; and $>2 \mathrm{~cm}$ for zexmenia). The first and second branches $>5 \mathrm{~cm}$ were counted for copper canyon daisy. Flowering characteristics were also quantified by counting the number of flower buds, open flowers, and faded flowers (Niu et al., 2013). Thereafter, all aboveground parts (including stems, leaves, and flowers) were harvested and DW was determined after oven-drying at $70{ }^{\circ} \mathrm{C}$ for $4 \mathrm{~d}$.

Foliar salt damage evaluation. Foliar salt damage was rated by giving a visual score based on a reference scale from 0 to 5 , where $0=$ dead; $1=$ over $90 \%$ foliar damage (salt damage: burning, necrosis, and discoloration); $2=$ moderate $(50 \%$ to $90 \%)$ foliar damage; $3=$ slight $(<50 \%)$ foliar damage; $4=$ good quality with minimal foliar damage; and $5=$ excellent with no foliar damage (Cai et al., 2014b). The foliar salt damage rating did not consider the plant size.

Leaf greenness. Leaf greenness (or relative chlorophyll content, SPAD reading) was measured using a handheld chlorophyll meter (measured as the optical density; Minolta Camera Co., Osaka, Japan) at the end of the experiment (on 3 Dec.). Healthy and fully expanded leaves in the middle of the shoot of surviving plants were chosen for measurements. Damianita was excluded due to its small leaves.

Chlorophyll fluorescence. Minimal florescence $\left(\mathrm{F}_{0}\right)$, maximum fluorescence $\left(\mathrm{F}_{\mathrm{m}}\right)$, the maximal photochemical efficiency of photosystem II $\left(\mathrm{F}_{\mathrm{v}} / \mathrm{F}_{\mathrm{m}}, \mathrm{F}_{\mathrm{v}}=\mathrm{F}_{\mathrm{m}}-\mathrm{F}_{0}\right)$, and performance index $\left(\mathrm{P}_{\mathrm{i}}\right)$ were measured using the Pocket PEA chlorophyll fluorescence system (Hansatech, Norfolk, UK) to examine the effect of elevated salinity on leaf photosynthetic apparatus for three species, i.e., gregg's mistflower, shasta daisy, and aromatic aster, on $11 \mathrm{Dec}$. Five plants per treatment were measured randomly. Other species were not measured because of small size of leaves.

Mineral analysis. To analyze shoot and leaf sodium $(\mathrm{Na})$, chloride $(\mathrm{Cl})$, potassium $(\mathrm{K})$, and calcium $(\mathrm{Ca})$ concentrations, four samples per treatment per species were randomly selected from the 10 samples. Dried tissue was ground to pass a 40-mesh screen with a stainless Wiley mill (Thomas Scientific, Swedesboro, NJ). Dried tissue samples were extracted with $2 \%$ acetic acid (EM Science, Gibbstown, $\mathrm{HJ}$ ) to determine $\mathrm{Cl}$ using the method described in Gavlak et al. (1994). The concentration of $\mathrm{Cl}$ was determined with a M926 Chloride Analyzer (Cole Parmer Instrument Company, Vernon Hills, IL). Dried tissue samples were submitted to the Soil, Water and Forage Testing Laboratory at Texas A\&M University (College Station, TX) for analyses of the foliar $\mathrm{Na}$, $\mathrm{Ca}$, and $\mathrm{K}$. In brief, dried tissue samples were digested in nitric acid following the protocol described by Havlin and Soltanpour (1989). $\mathrm{Na}, \mathrm{K}$, and $\mathrm{Ca}$ in digested samples were analyzed by inductively coupled plasma optical emission spectrometry (SPECTRO Analytical Instruments Inc., Mahwah, NJ) and reported on a dry plant basis as described by Isaac and Johnson (1975).

Statistical analysis. A two-way analysis of variance was used to test the effects of soil salinity and species on plant growth. Means separation among treatments was conducted using Tukey's honest significant difference multiple comparison. Relative shoot DW was calculated for each plant in EC 5 or EC 10 treatment as:

\section{Relative shoot DW (\%) \\ $=($ Shoot $\mathrm{DW}$ in control \\ - Shoot DW in salt treatment) \\ /Shoot DW in control $\times 100 \%$}

Similarly, relative values for height, crown diameter, number of shoots and flowers, and DW were calculated. These relative values were used as salt tolerance indexes for hierarchical cluster analysis (Zeng et al., 2002). The dendrogram of the 10 aster species was obtained based on Ward linkage method and squared Euclidian distance on the means of the salt tolerance indices for six multivariate parameters including all relative growth data. All statistical analyses were performed using JMP (Version 12; SAS Institute Inc., Cary, NC).

\section{Results and Discussion}

Leachate EC, substrate EC, and survival percentage. Species did not affect leachate EC and data were pooled across species. The average leachate EC of control treatment (nutrient solution at EC of $1.2 \mathrm{dS} \cdot \mathrm{m}^{-1}$ ) ranged from 3.1 to $5.4 \mathrm{dS} \cdot \mathrm{m}^{-1}$ during the experiment (Fig. 1). For EC 5 and EC 10, the leachate EC increased from 7.1 to $11.4 \mathrm{dS} \cdot \mathrm{m}^{-1}$, and from 9.5 to $18.1 \mathrm{dS} \cdot \mathrm{m}^{-1}$, respectively. From 18 Nov. (the fifth treatment) to the end of the experiment, all the plants were watered with nutrient solution $\left(\mathrm{EC}=1.2 \mathrm{dS} \cdot \mathrm{m}^{-1}\right)$, which resulted in the decrease of leachate EC in both EC 5 and EC 10 (Fig. 1). The substrate ECs were also unaffected by species, so the data of all species per treatment were pooled. The substrate ECs of control, EC 5, and EC 10 were $2.0 \pm 0.1,4.3 \pm$ 0.2 , and $6.9 \pm 0.5 \mathrm{dS} \cdot \mathrm{m}^{-1}$, respectively. The substrate EC increased as the salinity of irrigation water increased, indicating that more salts were accumulated in the rhizosphere.

Salinity at EC of 5.0 and $10.0 \mathrm{dS} \cdot \mathrm{m}^{-1}$ had no effect on the survival of damianita, gregg's mistflower, shasta daisy, lavender cotton, and skeleton-leaf goldeneye (Table 1). The survival percentages of aromatic aster, blackfoot daisy, copper canyon daisy, and zexmenia in EC 10 were $90 \%, 80 \%, 60 \%$, and $60 \%$, respectively. Four-nerve daisy had a survival percentage of $40 \%$ in EC 5 and $10 \%$ in EC 10. Salinity can impair plant function, growth, and developmental process and can also reduce survival as extreme (Taiz and Zeiger, 2015).

Plant height and crown diameter. Height of all species decreased as the EC of irrigation water increased except for blackfoot daisy and skeleton-leaf goldeneye (Table 2). EC 5 only reduced the height of damianita, 
shasta daisy, and lavender cotton (Table 2). The three most severe reductions in height were found in shasta daisy in EC 10 by $64 \%$, four-nerve daisy by $37 \%$, and damianita by $31 \%$, compared with control.

Saline water irrigation affected the crown diameter of nine species, with only gregg's mistflower growing unaffected by saline treatment (Table 2). Compared with their respective control, reductions of $31 \%, 25 \%$, and $23 \%$ were found in crown diameter for damianita, shasta daisy, and copper canyon daisy plants in EC 5, respectively. Crown

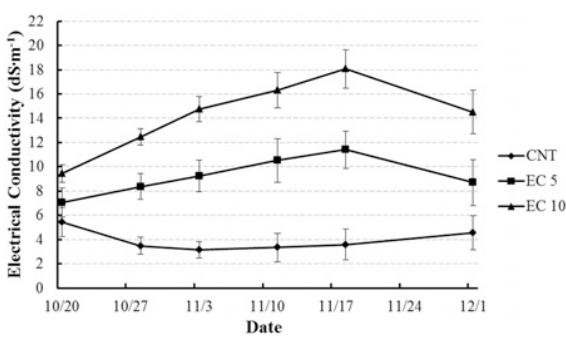

Fig. 1. Variation of weekly leachate electrical conductivity (EC) during the experimental period. Control (CNT) represents EC at 1.2 $\mathrm{dS} \cdot \mathrm{m}^{-1}$; EC 5 represents EC at $5.0 \mathrm{dS} \cdot \mathrm{m}^{-1}$; and EC 10 represents EC at $10.0 \mathrm{dS} \cdot \mathrm{m}^{-1}$. All plants were watered with the nutrient solution $(\mathrm{EC}=$ $1.2 \mathrm{dS} \cdot \mathrm{m}^{-1}$ ) after the fifth treatment on $17 \mathrm{Nov}$ till the harvest on 12 Dec. Data were pooled across all species since species did not affect leachate EC. Vertical bars represent SES.

Table 1. Survival percentage of 10 aster species irrigated with nutrient solution [electrical conductivity $(\mathrm{EC})=1.2 \mathrm{dS} \cdot \mathrm{m}^{-1}$; control] or saline solution $\left[\mathrm{EC}=5.0 \mathrm{dS} \cdot \mathrm{m}^{-1}(\mathrm{EC} 5)\right.$ or $10.0 \mathrm{dS} \cdot \mathrm{m}^{-1}$ (EC 10)] in the greenhouse.

\begin{tabular}{lcrr}
\hline & \multicolumn{3}{c}{ Survival percent } \\
\cline { 2 - 4 } Species & Control & EC 5 & EC 10 \\
\hline Aromatic aster & 100 & 100 & 90 \\
Blackfoot daisy & 100 & 100 & 80 \\
Copper canyon daisy & 100 & 100 & 60 \\
Damianita & 100 & 100 & 100 \\
Four-nerve daisy & 100 & 40 & 10 \\
Gregg's mistflower & 100 & 100 & 100 \\
Lavender cotton & 100 & 100 & 100 \\
Shasta daisy & 100 & 100 & 100 \\
Skeleton-leaf goldeneye & 100 & 100 & 100 \\
Zexmenia & 100 & 100 & 60 \\
\hline
\end{tabular}

Table 2. Height and crown diameter of 10 aster species irrigated with nutrient solution [electrical conductivity $(\mathrm{EC})=1.2 \mathrm{dS} \cdot \mathrm{m}^{-1}$; control] or saline solution $\left[\mathrm{EC}=5.0 \mathrm{dS} \cdot \mathrm{m}^{-1}(\mathrm{EC} 5)\right.$ or $10.0 \mathrm{dS} \cdot \mathrm{m}^{-1}(\mathrm{EC}$ 10)] in the greenhouse.

\begin{tabular}{lccrrrrr}
\hline & \multicolumn{3}{c}{$\mathrm{Ht}(\mathrm{cm})$} & & \multicolumn{3}{c}{ Crown diam $(\mathrm{cm})$} \\
\cline { 2 - 3 } Species & Control & EC 5 & EC 10 & & Control & EC 5 & EC 10 \\
\hline Aromatic aster & $13.1 \mathrm{a}$ & $10.9 \mathrm{ab}$ & $9.6 \mathrm{~b}$ & & $20.4 \mathrm{a}$ & $17.8 \mathrm{ab}$ & $15.9 \mathrm{~b}$ \\
Blackfoot daisy & $33.3 \mathrm{a}$ & $30.7 \mathrm{a}$ & $31.1 \mathrm{a}$ & & $28.1 \mathrm{a}$ & $24.5 \mathrm{ab}$ & $19.8 \mathrm{~b}$ \\
Copper canyon daisy & $34.8 \mathrm{a}$ & $31.3 \mathrm{ab}$ & $27.1 \mathrm{~b}$ & & $40.8 \mathrm{a}$ & $31.5 \mathrm{~b}$ & $18.4 \mathrm{c}$ \\
Damianita & $22.9 \mathrm{a}^{\mathrm{z}}$ & $17.1 \mathrm{~b}$ & $15.9 \mathrm{~b}$ & & $24.0 \mathrm{a}$ & $16.5 \mathrm{~b}$ & $14.7 \mathrm{~b}$ \\
Four-nerve daisy & $27.7 \mathrm{a}$ & $23.0 \mathrm{ab}$ & $17.4 \mathrm{~b}$ & & $19.1 \mathrm{a}$ & $16.9 \mathrm{a}$ & $8.5 \mathrm{~b}$ \\
Gregg's mistflower & $56.9 \mathrm{a}$ & $54.5 \mathrm{a}$ & $50.0 \mathrm{~b}$ & & $41.9 \mathrm{a}$ & $41.4 \mathrm{a}$ & $39.6 \mathrm{a}$ \\
Lavender cotton & $11.0 \mathrm{a}$ & $9.1 \mathrm{~b}$ & $8.6 \mathrm{~b}$ & & $17.1 \mathrm{a}$ & $16.1 \mathrm{a}$ & $13.8 \mathrm{~b}$ \\
Shasta daisy & $11.8 \mathrm{a}$ & $6.6 \mathrm{~b}$ & $4.3 \mathrm{c}$ & & $33.6 \mathrm{a}$ & $24.8 \mathrm{~b}$ & $21.8 \mathrm{c}$ \\
Skeleton-leaf goldeneye & $35.3 \mathrm{a}$ & $34.5 \mathrm{a}$ & $35.0 \mathrm{a}$ & & $31.3 \mathrm{a}$ & $27.3 \mathrm{ab}$ & $23.8 \mathrm{~b}$ \\
Zexmenia & $30.4 \mathrm{a}$ & $26.5 \mathrm{ab}$ & $21.8 \mathrm{~b}$ & & $17.8 \mathrm{a}$ & $15.3 \mathrm{ab}$ & $13.1 \mathrm{~b}$ \\
\hline
\end{tabular}

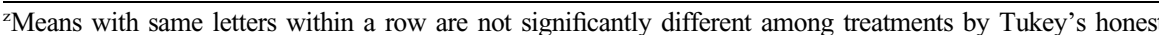
significant difference multiple comparison at $P \leq 0.05$.

diameters of the other seven species were not different between EC 5 and control. Crown diameter of four-nerve daisy, copper canyon daisy, and damianita had greater reduction in EC 10 compared with other species.

Number of shoots, number of flowers, and shoot $D W$. Except gregg's mistflower and aromatic aster, the number of shoots in the other seven species in EC 5 was reduced by $21 \%$ to $71 \%$ (Table 3 ). In addition, the number of shoots of all perennials in EC 10 was decreased except for four-nerve daisy. The highest reductions in the number of shoots were observed in EC 10 in damianita, copper canyon daisy, and blackfoot daisy by $91 \%, 63 \%$, and $61 \%$, respectively, compared with their respective control (Table 3).

Shasta daisy and lavender cotton did not flower throughout the period of experiment. Damianita, copper canyon daisy, and fournerve daisy in EC 5 had the greatest reductions in number of flowers by $91 \%$, $51 \%$, and $50 \%$, respectively, compared with their respective control (Table 3). No difference in number of flowers among treatments was found in blackfoot daisy and zexmenia. The number of flowers in damianita, copper canyon daisy, and four-nerve daisy decreased the most. Among all tested species, number of flowers of damianita was the most affected by increased salinity. Although number of flowers in gregg's mistflower was reduced significantly by elevated EC, plants in EC 10 still had more than 100 flowers and looked attractive. Niu et al. (2013) and Cai et al. (2014b) reported that salinity reduced the number of flowers and buds and flower DW of different Rosa spp. and cultivars. Elevated salinity reduced flower size and number in seven cultivars of Zinnia marylandica (Niu et al., 2012b).

Elevated salinity reduced DW of shoots in all species except for four-nerve daisy (Table 3). No difference in DW of shoots was found in gregg's mistflower, aromatic aster, and zexmenia between EC 5 and control. The DW of all the other species were all reduced in EC 5 and EC 10 compared with control. DW of shoots in copper canyon daisy, damianita, and shasta daisy in EC 10 was reduced by $66 \%, 64 \%$, and $59 \%$, respectively, compared with control. DW of shoots in lavender cotton, gregg's mistflower, zeximenia,

HortScience Vol. 51(2) February 2016 skeletion-leaf goldeneye, and aromatic aster plants in EC 10 was reduced between $21 \%$ and $41 \%$. It has been reported that increased salinity resulted in a reduction in shoot and leaf biomass in a variety of ornamental species (Cai et al., 2014b; Niu and Rodriguez, 2006; Niu et al., 2012a, 2012b). Based on the reduction of DW of shoots, copper canyon daisy and damianita were the most saltsensitive species among all tested plants, and lavender cotton and gregg's mistflower were more salt tolerant than others.

Foliar salt damage evaluation and salt tolerance cluster. Visual quality is an important parameter for ornamental plants. High soil salinity may cause deleterious effects such as necrosis and leaf edge burn on plant leaves (Wahome et al., 2001). Salt-tolerant plants usually have less foliar salt injury and less growth reduction at elevated salinity (Grieve et al., 2008). Gregg's mistflower and lavender cotton plants had good visual quality and minimal foliar damage in EC 5 and EC 10 treatments, and their averaged visual scores were above 4.5 (Table 4). Skeleton-leaf daisy plants had minimal foliar damage in EC 5 treatment and slight foliar salt damage in EC 10 treatment. Damianita and shasta daisy plants in EC 5 and EC 10 treatments exhibited slight foliar salt damage with averaged visual scores ranging from 2.9 to 3.5. Aromatic aster and copper canyon daisy plants in EC 5 experienced slight foliar salt damage. However, those in EC 10 had moderate to severe foliar salt damage with the averaged visual scores of 2.4 and 1.5, respectively. Zexmenia and four-nerve daisy plants displayed moderate to severe foliar salt damage in EC 5 treatment, and almost all fournerve daisy plants died in EC 10 treatment.

Hierarchical cluster analysis of the 10 aster species was conducted using multivariate parameters including the percentages of reductions in visual scores and growth parameters with the exclusion of number of flowers (Zeng et al., 2002). The dendrogram showed three distinguishable clusters in both EC 5 and EC 10 treatments (Fig. 2). Gregg's mistflower, skeleton-leaf goldeneye, lavender cotton, aromatic aster, and zexmenia were consistently clustered together in both EC 5 and EC 10 treatments and considered as the salt-tolerant group. In EC 5, blackfoot daisy, copper canyon daisy, and four-nerve daisy were clustered in the same group and considered to have moderate salt tolerance, whereas in EC 10 shasta daisy and four-nerve daisy were in the moderate salt-tolerant group. Damianita ranked in the salt-sensitive group in both salt treatments, whereas shasta daisy was also considered to be salt sensitive in EC 5 cluster, and blackfoot daisy and copper canyon daisy were classified as saltsensitive species in EC 10 cluster.

SPAD readings and chlorophyll fluorescence. All gregg's mistflower, lavender cotton, aromatic aster, four-nerve daisy, and skeletonleaf goldeneye plants in EC 5 and EC 10 had similar SPAD readings to those in control, indicating that salt treatment did not affect their chlorophyll content in per unit (Table 4). EC 5 
Table 3. Number of shoots and flowers, and dry weight $(\mathrm{DW})$ of shoots per plant of 10 aster species irrigated with nutrient solution [electrical conductivity $(\mathrm{EC})=$ $1.2 \mathrm{dS} \cdot \mathrm{m}^{-1}$; control] or saline solution $\left[\mathrm{EC}=5.0 \mathrm{dS} \cdot \mathrm{m}^{-1}(\mathrm{EC} 5)\right.$ or $\left.10.0 \mathrm{dS} \cdot \mathrm{m}^{-1}(\mathrm{EC} 10)\right]$ in the greenhouse.

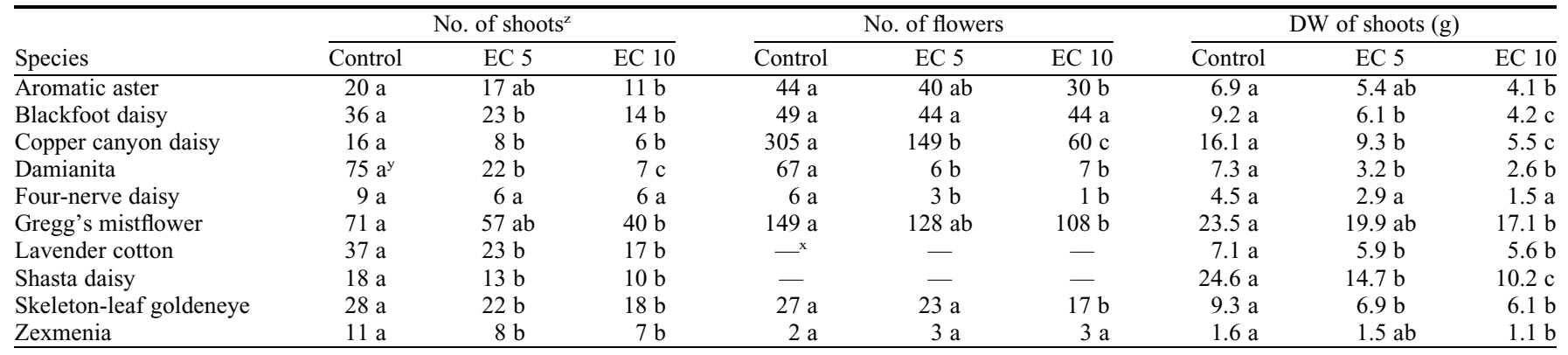

${ }^{\mathrm{z}}$ First and second branches of copper canyon daisy were counted. Number of branches were counted depending on the species $(>10 \mathrm{~cm}$ for gregg's mistflower, $>5 \mathrm{~cm}$ for damianita, blackfoot daisy, aromatic aster, and skeleton-leaf goldeneye, $>3 \mathrm{~cm}$ for lavender cotton, and $>2 \mathrm{~cm}$ for zexmenia). Number of crowns was counted for shasta daisy and four-nerve daisy due to rosette growth habit.

${ }^{y}$ Means with same letters within a row are not significantly different among treatments by Tukey's honest significant difference multiple comparison at $P \leq 0.05$.

${ }^{\mathrm{x}}$ Shasta daisy and lavender cotton did not flower during the experiment.

Table 4. Visual score and relative chlorophyll content (SPAD) of 10 aster species irrigated with nutrient solution [electrical conductivity $(E C)=1.2 \mathrm{dS} \cdot \mathrm{m}^{-1}$; control] or saline solution $\left[\mathrm{EC}=5.0 \mathrm{dS} \cdot \mathrm{m}^{-1}(\mathrm{EC} 5)\right.$ or $\left.10.0 \mathrm{dS} \cdot \mathrm{m}^{-1}(\mathrm{EC} 10)\right]$ in the greenhouse.

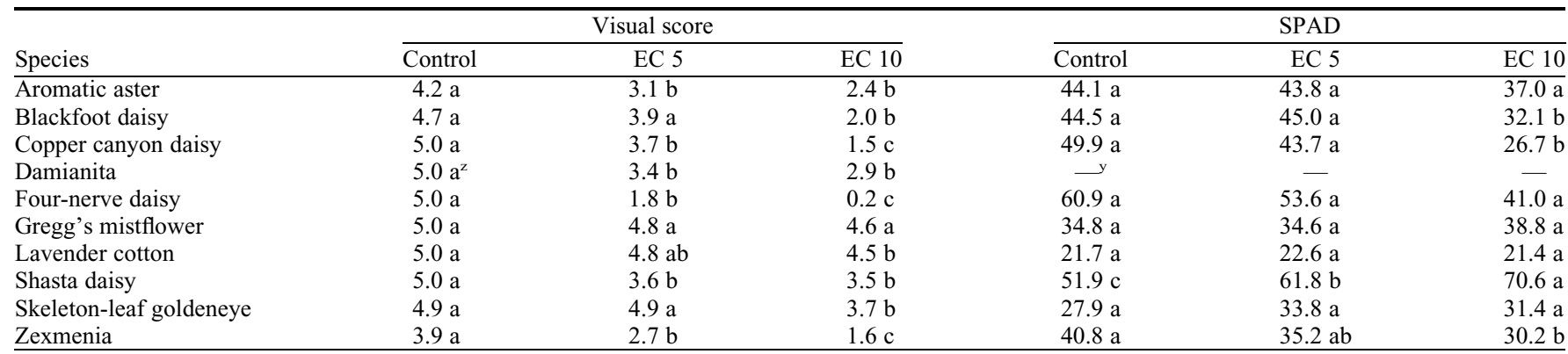

${ }^{\mathrm{z}}$ Means with same lowercase letters within a row are not significantly different among treatments by Tukey's honest significant difference multiple comparison at $P \leq 0.05$.

${ }^{\mathrm{y}} \mathrm{SPAD}$ was not measured for damianita due to small leaves.

did not impact the SPAD readings of blackfoot daisy, copper canyon daisy, and zexmenia, but EC 10 reduced their SPAD readings by $22 \%, 47 \%$, and $32 \%$, respectively, compared with control. Interestingly, SPAD readings of shasta daisy increased significantly with EC of irrigation solution.

Mineral analysis. The concentration of $\mathrm{Na}$ for blackfoot daisy, copper canyon daisy, skeleton-leaf goldeneye, and zexmenia in control was similar to that in EC 5 (Table 5). EC 5 significantly increased the $\mathrm{Na}$ concentrations of the other six species. Damianita and four-nerve daisy accumulated the most $\mathrm{Na}$, which was 28 and 31 times higher than those in control. EC 10 further increased the concentration of $\mathrm{Na}$ up to 59 and 62 times higher than those in control. Gregg's mistflower, shasta daisy, lavender cotton, aromatic aster, and zexmenia plants in EC 10 had 8 to 31 times higher $\mathrm{Na}$ than their respective control. The highest $\mathrm{Na}$ concentration $\left(35.6 \mathrm{mg} \cdot \mathrm{g}^{-1}\right.$ DW) was found in four-nerve daisy in EC 10.

Salt treatment also increased leaf $\mathrm{Cl}$ concentrations (Table 5). EC 5 increased the leaf $\mathrm{Cl}$ concentration of all tested plants by one to nine times, compared with their respective control, whereas EC 10 resulted in 3 to 21 times more $\mathrm{Cl}$ concentration in their leaves. The highest $\mathrm{Cl}$ concentration (139.4 $\mathrm{mg} \cdot \mathrm{g}^{-1} \mathrm{DW}$ ) was found in four-nerve daisy in EC 10. High concentrations of $\mathrm{Na}$ and/or $\mathrm{Cl}$ accumulated in leaf tissue may damage the chloroplasts and thus inhibit photosynthesis (Taiz and Zeiger, 2015). Excessive $\mathrm{Na}$ and $\mathrm{Cl}$ uptake also competes with uptake of other nutrient ions such as $\mathrm{K}, \mathrm{Ca}$, or nitrogen $(\mathrm{N})$, resulting in nutritional disorders and reduce plant quality (Grattan and Grieve, 1999). These might be the reasons why most of four-nerve daisy died and had poor visual quality in both EC 5 and EC 10 treatments.

Potassium plays an important role in the regulation of the osmotic potential of plant cell and also activates many enzymes involved in respiration and photosynthesis (Taiz and Zeiger, 2015). High accumulation of $\mathrm{Na}$ will subsequently cause the reduction of $\mathrm{K}$ contents (Hasegawa et al., 2000). Leaf K concentration decreased significantly with increasing EC in all species except in blackfoot daisy, aromatic aster, copper canyon daisy, and zexmenia (Table 5). Compared with control, damianita, four-nerve daisy, lavender cotton, shasta daisy, and skeletonleaf goldeneye accumulated $16 \%$ to $28 \%$ less $\mathrm{K}$ in their leaves in EC 5, whereas $29 \%$ to $56 \%$ in EC 10 .

Salt solution prepared with $\mathrm{NaCl}$ and $\mathrm{CaCl}_{2}$ also increased the leaf $\mathrm{Ca}$ concentration of all species except for gregg's mistflower. EC 5 treatment did affect the leaf $\mathrm{Ca}$ concentration of damianita, lavender cotton, and zexmenia. Four-nerve daisy and blackfoot daisy in EC 5 had the most increase in leaf Ca concentration of $104 \%$ and $99 \%$, whereas

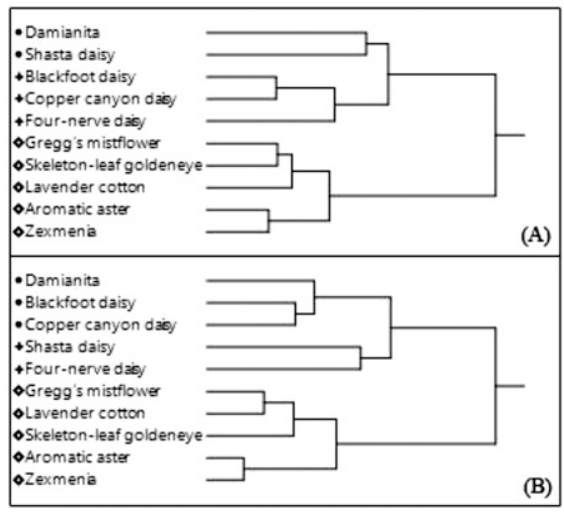

Fig. 2. Cluster analysis on the salt tolerance of 10 aster species according to the reduction of height, crown diameter, number of shoots, dry weight, and visual score as affected by elevated salinity at electrical conductivity of (A) 5.0 $\mathrm{dS} \cdot \mathrm{m}^{-1}$ and (B) $10.0 \mathrm{dS} \cdot \mathrm{m}^{-1}$.

those in EC 10 accumulated three and two times more $\mathrm{Ca}$ concentration in their leaves.

There are three distinct mechanisms of action for plants to adapt to salinity: osmotic stress tolerance, $\mathrm{Na}^{+}$or $\mathrm{Cl}^{-}$exclusion, and the tolerance of tissue to accumulated $\mathrm{Na}^{+}$or $\mathrm{Cl}^{-}$ (Munns and Tester, 2008). In many cases, salt-tolerant species have lower shoot $\mathrm{Na}^{+}$ and/or $\mathrm{Cl}^{-}$concentrations because they have the ability to restrict $\mathrm{Na}^{+}$and/or $\mathrm{Cl}^{-}$transport to shoots. However, some tolerant species 
Table 5. Na, $\mathrm{Cl}, \mathrm{K}$, and Ca concentrations of 10 aster species irrigated with nutrient solution [electrical conductivity (EC) $=1.2 \mathrm{dS} \cdot \mathrm{m}^{-1} ;$ control] or saline solution $\left[\mathrm{EC}=5.0 \mathrm{dS} \cdot \mathrm{m}^{-1}(\mathrm{EC} 5)\right.$ or $\left.10.0 \mathrm{dS} \cdot \mathrm{m}^{-1}(\mathrm{EC} 10)\right]$ in the greenhouse.

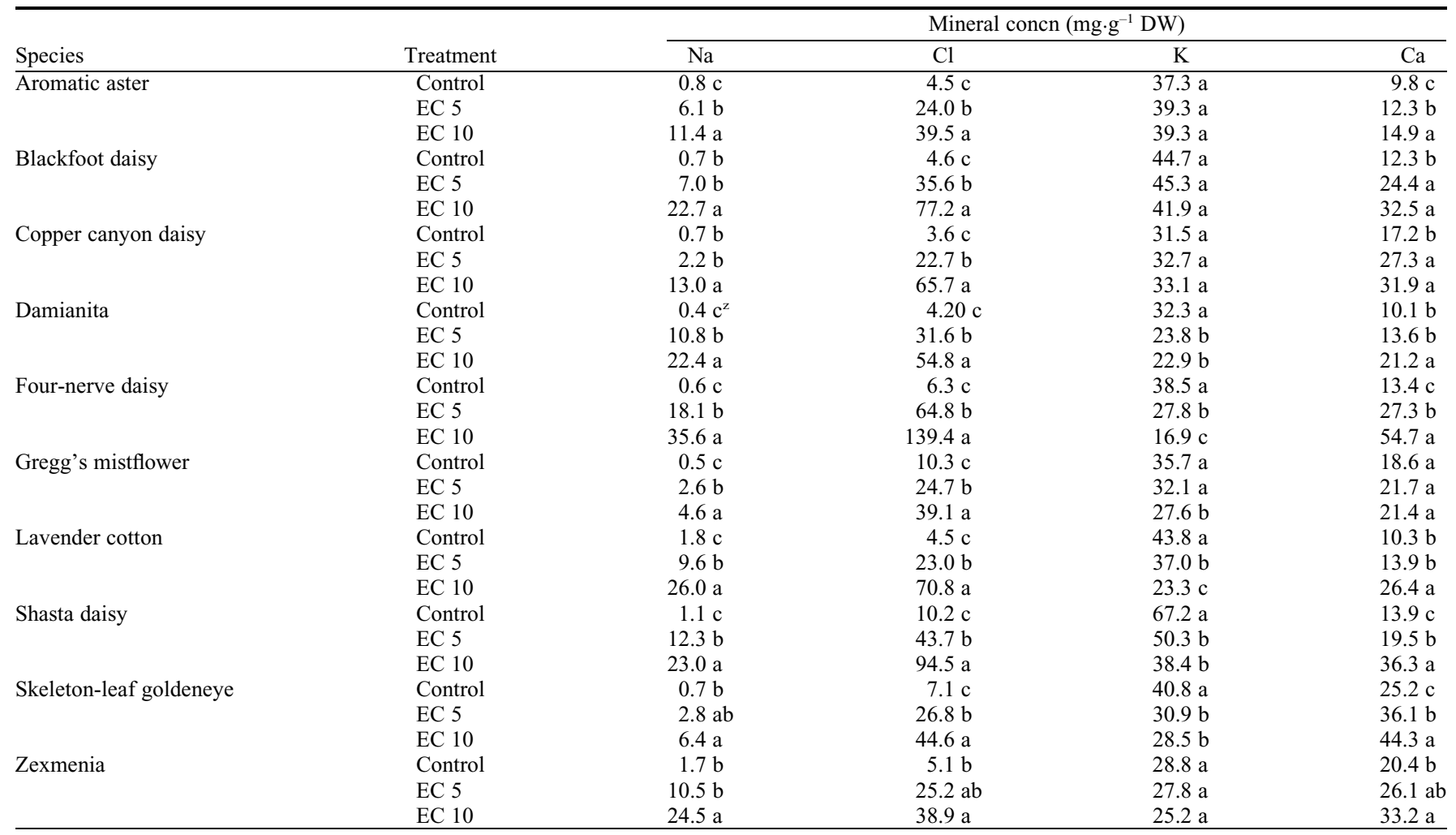

${ }^{2}$ Means with same lowercase letters within column for each species are not significantly different by Tukey's honest significant difference multiple comparison at $P \leq 0.05$.

can tolerate high internal $\mathrm{Na}^{+}$or $\mathrm{Cl}^{-}$concentrations such as lavender cotton in this study with high $\mathrm{Na}^{+}$and/or $\mathrm{Cl}^{-}$concentrations. Apparently, there were substantial differences in their mechanisms in dealing with salinity among the tested species.

\section{Conclusion}

Among the 10 species used in this study, gregg's mistflower, skeleton-leaf goldeneye, and lavender cotton were the most salttolerant species with less reductions in shoot DW at elevated salinity. Gregg's mistflower and skeleton-leaf goldeneye had relatively lower leaf $\mathrm{Na}$ concentration suggesting that these two species have strong capability to exclude Na. Damianita and the four daisies, i.e., blackfoot daisy, copper canyon daisy, four-nerve daisy, and shasta daisy, were salt sensitive due to their greater growth reduction, foliar salt damage, and high $\mathrm{Na}$ and $\mathrm{Cl}$ accumulation in leaves. Considering the relatively severe foliar salt damage and mortality, aromatic aster and zexmenia should be avoided in landscapes with elevated salinity.

\section{Literature Cited}

Cai, X., G. Niu, T. Starman, and M. Gu. 2014a. Salt-of-the-earth plants: Easing the pain of drought. Greenhouse Product News 24:32-36.

Cai, X., Y. Sun, T. Starman, C. Hall, and G. Niu. 2014b. Response of 18 Earth-Kind ${ }^{\circledR}$ rose cultivars to salt stress. HortScience 49:544-549.

Cavins, T.J., B.E. Whipker, and W.C. Fonteno. 2008. Pourthru: A method for monitoring nutrition in the greenhouse. Acta Hort. 779:289-297.
Gavlak, R.G., D.A. Horneck, and R.O. Miller. 1994. Plant, soil, and water reference methods for the western region. Western Reg. Ext. Publ. (WREP) 125. University of Alaska, Fairbanks, AK.

Grattan, S.R. and C.M. Grieve. 1999. Salinitymineral nutrient relations in horticultural crops. Sci. Hort. 78:127-157.

Grieve, C.M. 2011. Review irrigation of floricultural and nursery crops with saline wastewaters. Isr. J. Plant Sci. 59:187-196.

Grieve, C., L. Wu, L. Rollins, and A. Harivandi. 2008. Tolerance by landscape plants of salinity and of specific ions, p. 103-161. K. Tanji, S. Grattan, C. Grieve, A. Harivandi, L. Rollins, D. Shaw, B. Sheikh, and L. Wu (eds.). A comprehensive literature review on salt management guide for landscape irrigation with recycled water in coastal southern California. Southern California Salinity Coalition (SCSC) and National Water Research Institute (NWRI), Fountain Valley, CA. 7 July 2015. <http://www. salinitymanagement.org/>.

Hasegawa, P.M., R.A. Bressan, J.K. Zhu, and H.J. Bohnert. 2000. Plant cellular and molecular responses to salinity. Annu. Rev. Plant Physiol. Plant Mol. Biol. 51:463-499.

Havlin, J.L. and P.N. Soltanpour. 1989. A nitric acid and plant digest method for use with inductively coupled plasma spectrometry. Commun. Soil Sci. Plant Anal. 14:969-980.

Hawke, R.G. 2007. Chicago Botanic Garden Plant Evaluation Notes, Issue 30. A report on Leucanthemum $\times$ superbum and related daisies. Chicago Botanic Garden, Glencoe, IL. 7 July 2015. <http://www.chicagobotanic.org/downloads/ planteval_notes/no30_leucanthemum.pdf $>$.

Isaac, R.A. and W.C. Johnson. 1975. Collaborative study of wet and dry ashing techniques for the elemental analysis of plant tissue by atomic absorption spectrophotometry. J. Assoc. Off. Anal. Chem. 58:436-440.

Lady Bird Johnson Wildflower Center. 2015. Native Plants. 7 July 2015. <http://www.wildflower.org/>.

Meyer, S.E., R. Kjelgren, D. Morrison, and W.A. Varga. 2009. Landscaping on the new frontier: Waterwise design for the Intermountain West. Utah State Univ. Press, Logan, UT.

Munns, R. and M. Tester. 2008. Mechanisms of salinity tolerance. Annu. Rev. Plant Biol. 59:651-681.

Niu, G. and R.I. Cabrera. 2010. Growth and physiological responses of landscape plants to saline water irrigation: A review. HortScience 45:1605-1609.

Niu, G. and D.S. Rodriguez. 2006. Relative salt tolerance of selected herbaceous perennials and groundcovers. Sci. Hort. 110:352-358.

Niu, G., D.S. Rodriguez, and C. McKenney. 2012a. Response of selected wildflower species to saline water irrigation. HortScience 47:1351-1355.

Niu, G., T. Starman, and D. Byrne. 2013. Responses of growth and mineral nutrition of garden roses to saline water irrigation. HortScience 48:756-764.

Niu, G., M. Wang, and D. Rodriguez. 2012b. Response of zinnia plants to saline water irrigation. HortScience 47:793-797.

Taiz, L. and E. Zeiger. 2015. Plant physiology and development. 6th ed. Sinauer Associates, Inc., Publishers, Sunderland, MA.

Veatch-Blohm, M.E., D. Sawch, N. Elia, and D. Pinciotti. 2014. Salinity tolerance of three commonly planted Narcissus cultivars. HortScience 49:1158-1164.

Wahome, P.K., H.H. Jesch, and I. Grittner. 2001. Mechanisms of salt stress tolerance in two rose rootstocks: Rosa chinensis 'Major' and $R$. rubiginosa. Sci. Hort. 87:207-216.

Zeng, L., M.C. Shannon, and C.M. Grieve. 2002. Evaluation of salt tolerance in rice genotypes by multiples agronomic parameters. Euphytica 127:235-245. 